\title{
Influencers of Land Users' Perceptions of Land Resources: The Case of Mphosong-Bolahla Catchment, Lesotho
}

\author{
R. A. Mojaki ${ }^{1 *}$, K. J. B. Keregero ${ }^{1}$ \\ ${ }^{1}$ Faculty of Agriculture, National University of Lesotho, P.O. 180, Roma, Lesotho
}

Article History
Received: 22.06 .2020
Accepted: 08.08 .2020
Published: 30.04 .2021
Journal homepage:
http://www.easpublisher.com
Quick Response Code

Abstract: The study explored the research question: What are the influencers of land users' perceptions of land resources? It sought opinions of respondents on whether or not a list of identified circumstances were influencers of land users' perceptions of land resources. A structured interview schedule was used to collect data from 101 land users in Mphosong-Bolahla catchment area, who were selected using Nassiuma's [1] Formula. Data were analysed by descriptive statistics using the Statistical Package for Social Sciences (SPSS) computer programme version 20.0 and the findings were presented using statistical indicators, namely: means and standard deviations. The findings revealed that respondents were generally aware of the socio-economic, cultural and institutional influencers of land users' perceptions of their land resources. The socio-economic influencers were: ownership of freehold land and small landholdings, availability of off-farm income, employment, better market access, labour-intensive nature of land resource management, lack of access to consumer markets, insecurity of tenure, education, access to credit, and poverty. The cultural influencers were: rotational grazing, awareness of cropping systems and consequences, awareness of economic value of land, belief in land ownership as basis for personal and family identity, adherence to succession in land management, and belief that land is a cultural asset. The institutional influencers were: integration of stakeholders in planning management of rangeland resources, training for promotion of conservation technologies, access to conservation services, policy failures, and complexity of government procedures. The study concluded that land users recognise the existence of socio-economic, cultural and institutional influencers of their views on land resources and that this abundant wealth and resourcefulness ought to be optimised through their adequate involvement in decision-making regarding their land resources.

Keywords: Influencers, Perceptions, Land resources, Land users, Catchment.

Copyright ( ) 2021 The Author(s): This is an open-access article distributed under the terms of the Creative Commons Attribution 4.0 International License (CC BY-NC 4.0) which permits unrestricted use, distribution, and reproduction in any medium for non-commercial use provided the original author and source are credited.

\section{INTRODUCTION}

The perceptions of land users regarding land degradation constitute one of the important social factors determining their level of understanding of land degradation and its impacts on natural resource-based livelihoods and the environment. Consequently, these perceptions have a bearing on land users' level of support for, and participation in, the implementation of interventions to solve the problem of land degradation through the adoption of different alternatives and conservation practices. The span of perceptions of land degradation includes, but not limited to, their awareness of the problem, approaches to solving the problem, socio-economic interactions and economic capacity to solve the problem.

Concern for people's perceptions arises from the growing tendency of detaching economic and social assessments of land degradation from observable environmental features and human practices. Low [2], for example, noted that assessments of the current global economic and social impacts of land degradation are removed from the land use practices which degrade land and from the complex patterns of social causes and impacts. Breu et al., [3] posited that people's knowledge and their perceptions of the state of land resources, as well as their understanding of the basic 
processes involved in changing features of land resources are key to any effort towards sustainable land management. Consequently, Kangalawe [4] underscored the need to attach considerable importance to local views in the study of environmental change and land degradation.

According to Breu et al., [3], experience has shown that efforts to create better awareness of sustainable land management cannot rely solely on scientific knowledge as the understanding of local actors and other stakeholders must also be incorporated. Clearly, local and external knowledge and perceptions are both important. Thus, understanding local people's perceptions on environmental issues is a prerequisite for developing successful and sustainable resource management strategies. According to FAO [5], previous land degradation assessments have not moved much beyond the description and quantification of biophysical processes and their direct effects.

A study was recently completed in response to the desire by the Land Degradation Assessment in Dryland Areas (LADA) project for methodologies for land degradation assessment that seek to leverage socioeconomic perspectives of stakeholder communities as an integral component and starting point of biophysical assessment studies. The study explored the research question: What are the influencers of land users' perceptions of land resources? To address this question, a list of circumstances considered to influence the manner in which land users view their land resources was compiled. Respondents - land users - were then requested to indicate their opinions on whether these circumstances were influencers of land users' perceptions of land resources. The circumstances were pre-categorised as socio-economic, cultural and institutional.

\section{Methodology}

The study was cross-sectional and adopted a descriptive quantitative approach. The population of the study was land users in households in MphosongBolahla catchment area. To attain this, first, the list of households in the study area was obtained from chiefs on the basis of which the number of households was determined. Based on an estimated population of 1600 households, a random sample of 101 households was determined using Nassiuma's [1] formula for determining sample size for research activities [6]. The sampling unit was the elderly household member who uses land resources.

Data were collected using a structured interview schedule, which was checked for content validity by two officers from the Department of Soil and Water Conservation of the Ministry of Forestry, Range and Soil Conservation (MFRSC) and two academic staff members from the Department
Agricultural Economics and Extension of the National University of Lesotho. They reviewed the instrument and their views and suggestions were incorporated in the revised version that was eventually used for collecting data. The instrument was pretested for reliability using 25 land users who were excluded from the final survey. Based on the responses, the Cronbach's Alpha formula was used to determine the coefficient of reliability, which was 0.86 and considered suitable. The interviews were conducted by a trained team of research assistants and took place in respondents' homes. Data were subjected to descriptive statistical analysis using the Statistical Package for Social Sciences (SPSS) version 20.0.

\section{FINDINGS AND DiscuSSION Findings}

The opinions of respondents regarding the socio-economic, cultural and institutional circumstances deemed to influence land users' perceptions of their land resources were reflected in their rating of the extent to which they agreed with selected circumstances. The rating was based on a six-point Likert-type scale anchored as follows: $1=$ Strongly disagree; 2 = Disagree; 3 = Slightly disagree; $4=$ Slightly agree; $5=$ Agree and $6=$ Strongly agree. For purposes of interpretation of the findings, means ranging from 3.5 and above were considered to imply that respondents agreed with the circumstances reflecting influencers, while those below 3.5 were taken to imply the contrary.

\section{Opinions regarding socio-economic influencers of land users' views of land resources}

The findings revealed that respondents agreed that the following socio-economic circumstances influenced the manner in which land users view their land resources:

i. Ownership of freehold land prompting investments in land (Mean $=4.63)$;

ii. Ownership of small landholdings creating better understanding of land scarcity and consequent need to practice sustainable management practices $($ Mean $=4.52)$;

iii. Availability of off-farm income making people prefer to invest in land conservation measures $($ Mean $=4.50)$;

iv. Employment contributing to people's positive inclination to invest their income in land improvement $($ Mean $=4.50)$;

v. Better market access motivating increased investment in good land management practices (Mean = 4.44);

vi. The labour-intensive nature of land resource management $($ Mean $=4.36)$;

vii. Lack of access to consumer markets prompting people to invest in land conservation measures $($ Mean $=4.34)$; 
viii. Insecurity of tenure discouraging people from investing in land improvement (Mean = 4.33);

ix. Inclination of educated people to view land management practices positively (Mean $=4.00)$;

x. Preference of people with access to credit to use sustainable land management practices $($ Mean $=$ 3.77);

xi. Poverty that leads people to regard land as the only valuable asset they have (Mean $=3.66)$.

\section{Opinions regarding cultural influencers of land} users' views of land resources

According to the findings, respondents agreed that the following cultural circumstances influenced the manner in which land users view their land resources:

i. Rotational grazing that encourages sustainable use of land resource $($ Mean $=5.54)$;

ii. Awareness that bigger fields produce maize only, which is known to deplete soil nutrients (Mean = 5.53);

iii. Awareness that land is an economic asset that ought to be sustainably managed (Mean $=5.49$ );

iv. Belief that ownership of land provides a sense of identity $($ Mean $=5.48)$;

v. Established succession that encourages sound land management for the next generation (Mean $=5.31$;

vi. Inclination of land successors to engage in same farming practices on the same land that their forefathers left for them (Mean = 4.67);

vii. Belief that land is a cultural asset to be sustainably managed (Mean $=3.85)$.

\section{Opinions regarding institutional influencers of land users' views of land resources}

The institutional circumstances that were found to influence the manner in which land users view their land resources were as follows:

i. Integration of all stakeholders in planning management of rangeland resources $($ Mean = 5.63);

ii. Training for the promotion of conservation technologies to enhance sustainable land management practices $($ Mean $=5.48)$;

iii. Access to conservation services which encourage adoption of good land management practices $($ Mean $=5.46)$;

iv. Lack of access to conservation services which can cause land users to engage in unsustainable management practices (Mean = 5.42);

v. Policy failures that can deter land users from investing in land improvement (Mean = 5.37);

vi. Complex government procedures which discourage the poor from investing in land (Mean $=5.35)$.

\section{DISCUSSION}

Socio-Economic Influencers of Land Users' Views of Land Resources

The high rating accorded to "Ownership of freehold land prompting investments in land" is evidence that respondents recognised having legal custody of land as a very important factor influencing the way land users view land resources and any prospects of improving land. Kabubo-Mariara [7] noted that insecure land tenure can discourage land users from engaging in sustainable land management practices and may act as a disincentive to investment in sustainable agricultural practices and technologies. This view was echoed by Kasimbazi [8] who argued that insecure tenure is considered to lead land users to engage in land degradation and to even force the poor to adopt shortterm strategies, which are usually detrimental to the land, leading to resource degradation. Thus, having secure land is considered as an influencer of views pertaining to ensuring its sustainable management and reduction of its degradation.

Another highly rated situation was: "Ownership of small landholdings creating better understanding of land scarcity and consequent need to practice sustainable management practices". The finding underscores the fact that scarcity breeds preciousness, which makes those with limited land appreciate such a resource more and, therefore, consider the use of sustainable management practices on their land. According to Nakano et al., [9], neither small plot size nor limited landholding has negative relationship with the adoption of technologies.

The finding of "Availability of off-farm income making people prefer to invest in land conservation measures" can be explained by the fact that the amount of income may determine whether or not a farmer will implement sustainable land management [10]. That is, higher income provides more options and expands horizons, including enabling farmers to consider engaging in sustainable land management.

Inclination of educated people to view land management practices positively was also considered to influence the manner in which land users view their land resources. Indeed, investing in human capital is one of the keys to reducing poverty and adopting land conservation practices. Educated land users are more likely to make sense of recommended extension practices and adopt new technologies than their less educated or uneducated counterparts. Kassie et al., [11] viewed households with more education to have greater access to agricultural inputs that enhance productivity as a result of access to non-farm income and to be more aware of the benefits of sustainable land management strategies due to their ability to search, decode and apply new information and knowledge pertaining to sustainable land management.

The study confirmed the findings of Pender et al., [12] and von Braun et al., [13] that better market access motivates increased investment in good land management practices because of a reduction in 
transaction costs of access to inputs, such as improved seeds and fertilizers and improved access to output markets. Good access to markets is associated with increased opportunity costs of labour as a result of benefits accruing from alternative opportunities, hence discouraging the adoption of labour-intensive sustainable management practices, such as conservation farming [13]. Kirui and Mirzbaev [14] hypothesised that the farther away the farm is from markets, the less the likelihood of adoption of new seed varieties and fertilizers and the greater the likelihood of adoption of alternative sustainable management practices, such as conservation farming, crop rotation and manure application.

It should be noted, however, that while respondents agreed that poverty leads people to regard land as the only valuable asset available to them, they disagreed that poverty leads people to consider land as inexhaustible. These findings reveal the awareness by land users that land is a valuable resource that has to be nurtured and managed for sustainability of their livelihoods and should not be just taken for granted as God-given.

\section{Cultural influencers of land users' views of land resources}

The practice of rotational grazing that encourages sustainable use of the land resource was rated most highly as a cultural influencer of the way land users view land. As a practice, rotational grazing provides chance for previously used pastureland to recoup or recover its vegetation when animals move to the next pastureland. It is essential in preventing growth of invader species on rangelands, which are not only palatable to animals but also make such areas susceptible to land degradation. Nganga and Robinson [15] asserted that adherence to grazing patterns or rotational grazing is a key management option or intervention that also preserves ecosystems. It is evident from these findings that this cultural practice, which has become more or less a way of life for land users, has had great influence on how they view their land resources.

Awareness that bigger fields produce maize only, which is known to deplete soil nutrients, was rated second most highly as an influencer. According to Sserunkuuma [16], maize production exposes land to forces of erosion because it does not provide good soil cover. In addition, it is associated with export of nutrients from the farm, which leads to nutrient mining if nutrients are not replaced by use of external inputs. With many farmers increasingly adopting high-yielding maize varieties that mine more nutrients from the soil through increased harvests without using external inputs to replenish the lost nutrients, the importance of this factor as an influencer of land users' views of their land resources cannot be overemphasised.
Two related influencers also identified were "Awareness that land is an economic asset that ought to be sustainably managed" and "Belief that ownership of land provides a sense of identity". The findings reveal that the views of land users regarding their land resources are influenced by the value they attach to the land as an economic asset and the sense of satisfaction they derive from identifying themselves with it as owners. When people identify themselves with land, they manage it in a sustainable manner. Agatha [17] opined that ownership of land, especially that which is inherited from elders, gives a sense of identity and belonging to the individual, family and clan and this suggests that land users are more likely to engage in sustainable land management practices. This opinion is grounded in the fact that land is regarded not only as a cultural and spiritual asset, but also as an economic asset.

Other influencers of land users' views of their land resources were: established succession that encourages sound land management for the next generation, inclination of land successors to engage in same farming practices on the same land that their forefathers left for them, and belief that land is a cultural asset to be sustainably managed. All these circumstances point to the important role that inheritance and succession play in influencing the way in which land users view their land resources [17].

However, according to the findings, the belief that land is a gift from the creator was not considered to be an influencer of the views of land users regarding their land resources. That is, respondents did not take the availability of land for granted and did not hold the idea that land should be used in any way people want. This finding is in line with that of Agatha [17] that land has to be guarded and sustainably used by the family. This opinion reinforces the cultural and almost spiritual significance attached to land by its users and underscores the economic significance attached to their views of land resources.

\section{Institutional influencers of land users' views of land resources}

According to the findings, land users' views on land resources were greatly influenced by the integration of all stakeholders in planning management of rangeland resources. These findings point to the contribution of stakeholder involvement in enriching the views that people hold regarding their land resources. They reflect the significance of people's participation in their own development efforts [18] and the valuable learning derived from it.

Training for the promotion of conservation technologies to enhance sustainable land management practices was identified as the second most important influencer. It is evident from this finding that respondents considered training to influence the way 
land users view their land resources. Moges and Taye [19] found a positive and very significant correlation between farmers' motivation to invest in SLM technologies and their access to training related to sustainable soil conservation and management.

Training as an influencing factor is also closely related to two other factors, namely "Access to conservation services which encourage adoption of good land management practices" and "Lack of access to conservation services which can cause land users to engage in unsustainable management practices". That is, respondents attributed some of the influence on land users' views of their land resources to the contribution or lack of extension services. Farmers with access to training through extension are likely to be more aware of conservation technologies and their benefits than those without. Access of farmers to training and their participation in extension workshops improves their perception of soil erosion problems and facilitates the use of conservation technologies [20].

The findings also revealed that views of land users on land resources are influenced by clear and enabling government policies as well as user-friendly and straightforward government and institutional procedures. Of no less significance is the simplicity and clarity of land ownership rules. The implication here is that policy failures that can deter land users from investing in land improvement and complex government procedures discourage the poor in a similar manner.

\section{Conclusions and Recommendations}

The influencers of land users' perceptions of land resources are socio-economic, cultural and institutional. The socio-economic influencers are: ownership of freehold land and small landholdings, availability of off-farm income, employment, better market access, labour-intensive nature of land resource management, lack of access to consumer markets, insecurity of tenure, education, access to credit, and poverty. The cultural influencers are: rotational grazing, awareness of cropping systems and consequences, awareness of economic value of land, belief in land ownership as a basis of personal and family identity, adherence to succession that encourages sound land management, and belief that land is a cultural asset that ought to be sustainably managed. The institutional influencers are: integration of stakeholders in planning the management of rangeland resources, training for promotion of conservation technologies, access to conservation services, policy failures, and complexity of government procedures.

Since land users are aware of the socioeconomic, institutional and cultural influencers of their views on land resources, consideration of the reality in which they live and operate is of paramount importance in sustainable land management (SLM). Thus, the wealth of knowledge and experience accumulated by land users exert crucial influence on the manner in which they perceive their land resources.

Based on the conclusions of the study, it is recommended that the MFRSC and Ministry of Agriculture and Food Security, through their extension departments, should embrace the importance of socioeconomic, cultural and institutional influencers of land users' perceptions of land resources by ensuring that land users are adequately trained and enabled to be part of the decision-making equation in their communities. This will enable them to leverage the socio-economic, cultural and institutional environments in which they operate.

\section{REFERENCES}

1. Nassiuma, D. K. (2000). Survey sampling. Theory and methods, 10(1), 59-63.

2. Low, P. S. (2013). Economic and social impacts of desertification, land degradation and drought. In: White Paper I, UNCCD 2nd Scientific Conference. Bonn, Germany.

https://profiles.uonbi.ac.ke/jmariara/files/unccd_wh ite_paper_1.pdf.17/10/2017.

3. Breu, T. M., Hurni, H., Portner, B., Schwilch, G., Wolfgramm, B., Messerli, P., \& Herweg, K. G. (2011). Sustainable land management and global development: factors affecting land users' efforts to adopt and sustain the productive use of natural resources.

https://www.researchgate.net/publication/23544361 6_Sustainable_Land_Management_and_Global_De velopment_Factors_Affecting_Land_Users'_Effort s_to_Adopt_and_Sustain_the_Productive_Use_of_ Natural_Resources.09/07/2018.

4. Kangalawe, R. Y. (2012). Land degradation, community perceptions and environmental management implications in the drylands of central Tanzania. In: Curkovic, S. (Ed.). Sustainable Development-Authoritative and Leading Edge Content for Environmental Management. Institute of Resources Assessment, University of Dar es Salaam, Dar es Salaam, Tanzania.

5. FAO. (2016). Informing future interventions for scaling-up sustainable land management. http://www.fao.org/3/a-i5621e.pdf. 01/06/2017.

6. Ali-Olubandwa, A. M., Odero-Wanga, D., Kathuri, N. J., \& Shivoga, W. A. (2010). Adoption of improved maize production practices among small scale farmers in the agricultural reform era: the case of western province of Kenya. Journal of International Agricultural and Extension Education. 17(1): 21-30.

7. Kabubo-Mariara, J. (2007). Land conservation and tenure security in Kenya: Boserup's hypothesis revisited. Ecological Economics. 64 (1): 25-35. 
8. Kasimbazi, E. (2017). Land tenure and rights. https://static1.squarespace.com/static/5694c48bd82 d5e9597570999/t/5931662a8419c273d641e910/14 96409643876/Land+Tenure+and+Rights__E_Kasi mbazi.pdf.23/08/2018

9. Nakano, Y., Tsusaka, T. W., Aida, T., \& Pede, V. O. (2018). Is farmer-to-farmer extension effective? The impact of training on technology adoption and rice farming productivity in Tanzania. World Development. 105, 336-351.

10. William, A. A. (2016). Socio-economic determinants of sustainable land management practices among smallholder farmers in Sabatia Sub-County. University of Nairobi, Nairobi, Kenya.

11. Kassie, M., Shiferaw, B., \& Muricho, G. (2011). Agricultural technology, crop income, and poverty alleviation in Uganda. World Development. 39(10):1784-1795.

12. Pender, J., Nkonya, E., Jagger, P., Sserunkuuma, D., \& Ssali, H. (2006). Strategies to increase agricultural productivity and reduce land degradation in Uganda: an econometric analysis of strategies for sustainable land management in East African Highlands. International Food Policy Research Institute, Washington D.C., USA.

13. Von Baun, J., Gerber, N., Mirzabaev, A., \& Nkonya, E. (2012). The economics of land degradation. An Issue Paper for Global Week, 0822 November, 2012. Berlin, Germany.

14. Kirui, O., \& Mirzabaev, A. (2015). Drivers of land degradation and adoption of multiple sustainable land management practices in Eastern Africa. In: International Conference of Agricultural Economists 29 Milan, Italy, 2015. International Association of Agricultural
Economists.https://ageconsearch.umn.edu/bitstrea $\mathrm{m} / 212008 / 2 /$ Kirui-

Drivers $\% 20$ of $\% 20$ land $\% 20$ degradation $\% 20$ and $\% 2$ 0adoption\%20of\%20multiple\%20sustainable\%201a nd\%20management $\% 20$ practices1021.pdf.29/07/2018.

15. Nganga, I. N., \& Robinson, L. W. (2016). Factors influencing natural resource management in pastoral systems: case of Tana River County. Nairobi, Kenya.

16. Sserunkuuma, D. (2002). Land management problems and potential in the lakeshore intensive banana-coffee farming system. Makerere University, Kampala, Uganda.

17. Agatha, A. (2016). Traditional wisdom in land use and resource management among the Lugbara of Uganda: a historical perspective. SAGE Open, 6(3),

2158244016664562.http://journals.sagepub.com/do i/pdf/10.1177/2158244016664562.

18. Duraiappah, A. K., Roddy, P., \& Parry, J. E. (2005). Have participatory approaches increased capabilities?. International Institute for Sustainable Development.

https://www.iisd.org/pdf/2005/economics_participa tory_approaches.pdf.25/08/2018.

19. Moges, D. M., \& Taye, A. A. (2017). Determinants of farmers' perception to invest in soil and water conservation technologies in the North-Western Highlands of Ethiopia. International Soil and Water Conservation Research. 5(1): 56-61.

20. FAO. (2011). Sustainable land management in practice: guidelines and best practices for SubSaharan Africa. Rome, Italy.

Cite This Article: R. A. Mojaki \& K. J. B. Keregero (2021). Influencers of Land Users' Perceptions of Land Resources: The Case of Mphosong-Bolahla Catchment, Lesotho. East African Scholars J Agri Life Sci, 4(4), 106-111. 